\title{
On Standing's A Precariat Charter: Confronting the Precaritisation of Labour in Brazil and Portugal
}

\author{
Ruy Braga, University of São Paulo, Brazil
}

\begin{abstract}
Guy Standing's new book, A Precariat Charter, does not allow us to forget that we live under the shadow of the "precariat" - a group of people who are deprived of any work-related guarantees, subjected to uncertain income, and without a collective identity that is rooted in a labour world. Among the many merits of his most recent book, Standing reports the damaging effects suffered by a substantial section of the European trade union movement. At the root of this decline is labour's submission to a socially irresponsible and environmentally unsustainable model of development. First, I will examine the book from a Southern perspective. The data and examples that Standing provide pertain largely to changing working-class relations in advanced capitalist countries. In contrast, I will focus my attention on the metamorphosis of the working class in the Global South - particularly Brazil - during the post-Fordist era in order to raise questions about the class character of the precariat.
\end{abstract}

\section{KEY WORDS}

precariat; unionism; Brazil; Portugal; social movements; Global South

\section{Introduction}

Guy Standing's most recent book, A Precariat Charter, does not allow us to forget that we live under the shadow of the "precariat" - a group of people who are deprived of any work-related guarantees, subjected to uncertain income, and without a collective identity that is rooted in a labour world (Standing, 2014). Among the many merits of this book, Standing reports the damaging effects suffered by a substantial section of the European trade union movement. At the root of this decline is labour's submission to a socially irresponsible and environmentally unsustainable model of development.

As with Standing's (2011) previous volume on the precariat, there is much that is praiseworthy in A Precariat Charter. But by raising provocative and challenging questions, studies of this magnitude also encourage productive debate. In this spirit, I am going to challenge and extend Standing's argument by examining the book from a Southern perspective. The data and examples that Standing provides pertain largely to changing working-class relations in advanced capitalist countries. In contrast, I will focus my attention on the metamorphosis of the working class in the Global South particularly Brazil - during the post-Fordist era.

First, Guy Standing supports the idea that the precariat is a new class and that it is changing. We could say that the advent of this new class accompanied the process of "Brazilianisation" of advanced capitalism, promoted by neo-liberal globalisation. "Brazilianisation" of advanced capitalism refers to: 
(a) the increasing informalisation of jobs, (b) the decline of unionisation rates in the Global North, and (c) the retreat of social protection for workers. Therefore, a look at the formation of the postFordist precariat in Brazil may be useful to contextualise the scope and boundaries of Standing's analysis.

Second, it seems that Standing's political conclusions about the relationship between the precariat and social struggles - that is, the precariat as a "new dangerous class" potentially close to authoritarian solutions for the current economic crisis - derive conceptually from the separation between the precariat and the working class. In order to interpret the precariat's political behaviour in a way that is more aligned with new developments in, for example, southern Europe (Portugal, Spain and Greece) and Latin America (Brazil), this article follows a Marxist agenda according to which the precariat is formed mainly by the most exploited and dominated fractions of the working class. Although there is a political barrier between the precariat and the trade union movement, erected by union bureaucracy, there is no insurmountable contradiction between them.

Finally, I intend to analyse Standing's main proposal, intended to inspire the political action of the precariat - the universal basic income agenda. Therefore, this article briefly examines the Brazilian example of the universal basic income experience - the Bolsa Familia programme (BFP) - in order to argue that although the universal basic income is attractive to the Brazilian sub-proletariat, the main source of political attraction for the Brazilian precariat remains the struggle for their citizenship rights. In this sense, the precariat tends to approach the labour movement and not depart from it.

\section{From Peripheral Fordism to Global Precariat: The "Brazilianisation" of Advanced Capitalism?}

My main argument here is that the rise of the precariat both in Brazil and Portugal suggests that this group is part of the working class and is more likely to find allies among trade union leaderships than among the well-intentioned technocrats that Standing refers to in The Precariat Charter. If precariousness is becoming the norm, it may well threaten decades of the institutionalisation of social rights in advanced capitalist countries. However, the truth is that it was never the rule on the periphery of the system. Is this one more sign of the "Brazilianisation" of advanced capitalism? Or is it simply a demonstration that capitalist development, beyond being permeable to a plurality of rhythms, is not directed by any progressive telos, revealing itself, on the contrary, as combined and unequal?

The assumption is that the post-Second World War industrialisation process in countries such as Portugal and Brazil was characterised by the superation of primitive Taylorism (even though, especially in the textile and electronics industries, primitive Taylorism endured as a management strategy to control labour). They were thus accumulation regimes supported by low-productivity industries and oriented to the export of non-durable consumer goods to other peripheral Fordist countries. The notion of peripheral Fordism designates the process of mechanisation associated with intensive capital accumulation and the growth of a durable consumer market that, in the Brazilian case, began in the 1950s and extended to the early 1990s with the advent of neo-liberalism and the integration of the national economy within the process of capitalist globalisation.

Thus there exists an articulated system of capitalist, pre-capitalist and semi-capitalist social relations dominated by the world market. In a nutshell, the global market was structured by a combination of developed and underdeveloped capitalist nations in a multilateral, self-conditioning system. In this social system, dominated by the globalisation of commercial exchanges, the formation 
of peripheral Fordism represented one of the principal historical mediations between the advanced capitalist and the underdeveloped capitalist countries.

The "peripheral" character of this social system arose from the fact that the most skilled levels of manufacturing, especially in the engineering sectors, remained outside these countries. Moreover, from the point of view of durable consumer goods, the economic dynamics were focused on raising the purchasing power of the local middle class at the expense of a decline in the consumption capacity of workers, resulting in inflation, a rise in labour productivity, wage degradation, workforce turnover, and so on. The productivity gains achieved by mechanisation were not passed onto the salaries of workers, helping to reinforce the proletarian and semi-proletarian army that was effectively underemployed through the restrictions of workers' needs.

Finally, the peripheral Fordist development model was supported by an articulation between import substitution policies and a shift in the content of exports towards durable consumer goods coupled with a resumption of imports of capital goods from the central countries. Thus, during the post-Second World War period, peripheral Fordism became the predominant development model in these countries. It is important to note that the transition from international Fordism to globalised post-Fordism reproduced these asymmetries. Surprisingly, Guy Standing did not deal with these structural features in his analysis of the emergence of the global precariat.

Actually, as Jan Breman notes, it is unlikely that Standing is unaware of the condition of the precariat in the Global South given his background:

An economist at the International Labour Organization from 1975 until 2006, Guy Standing should be well placed to address these questions. Though his recent work has focused largely on the condition of labour in the Western world, he is well acquainted with the precarious nature of work and life for most people in the global South; he has been a presence at international seminars and conferences discussing the vulnerability of workers in the informal economy for many decades. His first publication with the ILO was a scholarly treatise on labour-force participation in low-income countries in 1978, followed by labour-force studies on Jamaica, Guyana, Malaysia, Thailand and elsewhere. In the mid-80s, Standing was responsible for a series of ILO analyses of labour-market 'flexibility' in the OECD countries, which took a sceptical view of neoliberal nostrums while accepting that the capitalist economies had entered a new era, marked by unemployment and fiscal crises. In the early 90s he switched to Russia, editing In Search of Flexibility: The New Soviet Labour Market (1991) for the ILO, followed by post-Apartheid South Africa with Restructuring the Labour Market: The South African Challenge (1996) (Breman, 2013: 131).

The class character of the precariat also has to be addressed. Standing (2014) reaffirms that the precariat is not a part of the working class, a label which he reserves for unionised workers in stable employment. In my opinion, this definition is closer to the concept of "salariat" created by economists from the French Regulatory School, which describes a social norm of consumption found in the Fordist model of development. According to Standing, the precariat constitutes a class "in transformation", a by-product of capitalist globalisation and its concomitant strategies to make working conditions more flexible. However, from the point of view of Brazil and Portugal, we should not forget that precariousness has always been a constitutive part of the working-class condition.

Global Labour Journal, 2016, 7(2), Page 150 


\section{The Precariat as "Precarious Proletariat": Following a Marxist Agenda}

It is important to note that this article discusses the precariat according to Marxist terms. Standing shares the sociological understanding that precariousness is a condition located outside the wage relationship. In other words, if it were not for neo-liberalism and the current global economic crisis, the institutionalisation of citizenship rights through the wage relation would certainly replace precariousness through social protection. I argue to the contrary - that, due to the commodification of labour, the capitalist character of the division of labour and the anarchy of the reproduction of capital, precariousness is actually constituent of the wage relation. Consequently, the precariat should not be defined as the antipode of wage labour, as a repressed "bastard". In fact, the Fordist compromise showed itself quite adept at protecting the professional, white, male, adult, national and unionised fractions of the working class at the expense of the unskilled or semiskilled, female, black, young and immigrant working class.

Standing (2014) identifies the particularity of Fordist citizenship with the totality of the wage relation. Thus, the insecurity of employment and the permanent threat of socio-economic exclusion that marks the reality of a growing number of young people entering the labour market appear to him as a ghost straight out of the nineteenth century. It is worthwhile remembering here that at the height of the Victorian era, long before Fordism took its first steps, Marx (2013: Chapter 25) had exorcised this spirit by associating the increased number of industrial occupations with the formation of a surplus population. Thus, he argued that it was capitalist accumulation itself that despotically produced - in the form of unemployment or precarious work - a surplus working population necessary to the capitalist mode of production and clumped around four distinct, but mutually permeable, fractions. Given the dynamics of capitalist investment and the acceleration of the consumption of labour power, the floating population comprised those workers who were sometimes attracted to and sometimes repelled by companies. The latent population consisted of non-industrial workers and youth waiting for an opportunity to leave traditional sectors, especially the rural areas, in order to establish themselves in industry. The stagnant population, in turn, constituted a part of the workforce occupying decrepit and poorly paid jobs, resulting in their living conditions falling to substandard levels of existence. Finally, the pauperised population comprised the mass of impoverished, indigent, sick and injured workers, as well as those too old to work. In addition to the description of each of these types, what stands out in Marx's analysis is his ability to relate the progress of labour productivity made by industry to the deterioration of the living conditions of the urban proletariat and rural workers.

In my view, the precariat - that is, the precarious proletariat - consists of what Marx called the "relative surplus population". ${ }^{1}$ This definition seems to be more precise than that advanced by Standing. First, it allows us to locate the precariat in the heart of the capitalist mode of production and not as

\footnotetext{
1 This excluded both the lumpenproletariat and the impoverished portion of the population. Marx described the lumpenproletariat as "the refuse of all classes". Formed "alongside ruined and adventurous offshoots of the bourgeoisie, [they] were vagabonds, discharged soldiers, discharged jailbirds, escaped galley slaves, swindlers, mountebanks, lazzaroni, pickpockets, tricksters, gamblers, maquereaux [pimps], brothel keepers, porters, literati, organ grinders, ragpickers, knife grinders, tinkers, beggars..." (Marx, 2011. Through this category, Marx aimed to draw attention to the deepening social degradation, especially prominent in times of crisis, that a large number of individuals were submitted to, separating them from their originating class and turning them into a "disintegrated mass" vulnerable to reactionary movements. On the relation between the lumpenproletariat and the emergence of Nazi Fascism in Germany, see Trotsky (1979). However, it is worth remembering that neither Marx nor Trotsky explored conceptually the relation between the pauperised population and the lumpenproletariat.
} 
a by-product of the crisis of Fordist development. Second, it emphasises the historical and relational dimension of this group as part of the working class and not as an intergenerational and multiclass amalgam that would progressively emerge as a new class. ${ }^{2}$ Third, instead of arbitrarily removing the insecurity of the wage relation, this notion enables us to treat precariousness as an intrinsic dimension of the process of the commodification of labour. To support my interpretation of the precariat and the concept of relative surplus population, I follow the suggestion of Paul M. Sweezy:

In this connection let me call attention to Chapter 17 [of the classic study by Harry Braverman], 'The Structure of the Working Class and Its Reserve Armies', where the thesis is put forward that Marx's 'General Law of Capitalist Accumulation', according to which the advance of capitalism is characterized by the amassing of wealth at one pole and of deprivation and misery at the other, far from being the egregious fallacy which bourgeois social science has long held it to be, has in fact turned out to be one of the best founded of all Marx's insights into the capitalist system. How much more coherent and useful the voluminous literature of recent years on poverty and related questions would be if it had started from this solid foundation! (Sweezy, 1998: xxvii).

Moreover, we must analytically distinguish pauperism (and the lumpenproletariat) from the precariat, because precarious workers are a part of the working class in constant transit between the possibility of socio-economic exclusion and the deepening of economic exploitation:

...the higher the productivity of labour, the greater is the pressure of the workers on the means of employment, the more precarious therefore becomes the condition for their existence, namely the sale of their own labour-power for the increase of alien wealth, or in other words the self-valorization of capital (Marx, 1992: 798).

In falling into pauperism, these workers fail to fulfil any relevant function in relation to the economic exploitation of class, conforming themselves to what Marx called "the hospital of the active labourarmy and the dead weight of the industrial reserve army" (Marx, 1992: 797).

The need to define the general limits of the precariat also requires us to differentiate it from the professional sectors - that is, more qualified, well-paid and therefore more stable workers. In short, I identify the precariat with the poorly paid and exploited urban proletariat and farm workers (excluding the pauperised population and lumpenproletariat), since they are central to the reproduction of peripheral capitalism. Under this perspective, the present deepening of job insecurity on a global scale is not a surprise: it is supported by the increase in the exploitation of the workforce, and above all by the plundering of social rights. It is a regression in terms of civilisation, enhanced by a long period of deceleration in capital accumulation since the 1970s. How should we interpret this regression, which leads us to a new relationship between the youth and the trade unions?

\footnotetext{
2 Because they have few skills, do not exercise authority and do not contract labour, precarious workers are the most subordinate and exploited fraction of the working class.
} 


\section{The Precariat and Trade Unions}

To a certain extent Standing's analysis hits the nail on the head, particularly when it comes to new arrivals to the labour market such as interns and telemarketing operators. As he suggests, these young workers are dealing with frustrated occupational ambitions, which cannot compare to the occupational stability often enjoyed by their parents. But if Standing accurately captures the insecurity of these young workers, his characterisation of their relationship to trade unions deserves to be problematised. For him, young workers in precarious employment are hostile to trade unions due to both their lack of political experience and the precariousness of their labour, which together make it practically impossible to organise at the workplace. This supposition leads him to underestimate the precariat's self-organisation capacity, and to overshadow the capacity for trade unions to adapt to new realities at work.

In A Precariat Charter, Standing suggests that the precariat will only be well-represented through agencies of social and economic governance. By attempting to "inspire action" in the precariat through an "alternative political agenda to a utilitarian democracy", Standing (2014) directs the politics of the precariat towards the reform of public policies. After all, if the trade unions are condemned to disappearance, as Standing believes, evidently they are unable to propose solutions that would strengthen the universalisation of social rights and confront the precaritisation of labour. But what would happen if precaritised young workers viewed trade unions more positively - not as representing the unobtainable privileges of previous generations, but rather as potentially making it possible to access the social rights denied to their parents? In other words, what would happen if the precariat is seen as part of the working class and not a new class with opposing interests to the unions?

The complement to Standing's under-estimation of formal trade unionists is his tendency to project onto the precariat a set of "objective" interests and then to assume that policy initiatives that conform to these interests would ignite the loyalties of the precariat towards bureaucratic policy instead of encouraging a closer approach to unionism. In this sense, a curious incident took place when, in 2004, I first started my field research on São Paulo's telemarketing operators. Similar to Standing, I had doubts about the trade union consciousness of these young workers. As the research evolved, however, I realised that my expectations of workers in the telemarketing sector did not match the reality. To a certain degree, my perception changed with the metamorphosis of the Brazilian Call Centre industry itself - mergers and acquisitions of companies followed by stringent target rules, routinisation of work, managerial despotism, high levels of personnel turnover and low wages. All of these conditions fed into workers' critical attitude to the companies (Antunes and Braga, 2010). This critical orientation provided a basis for bringing together the precariat and the trade unions. Despite their political inexperience, the telemarketing operators turned to unions for support with respect to their labour claims.

\section{Brazil: the experience of Sintratel}

Trade unions in Brazil have done a remarkable job of transforming themselves in order to reach out to groups of precaritised workers. How do unions develop strategies to organise such workers and build solidarity for collective action? One of the three biggest unions organising telemarketing operators in São Paulo city, Sindicato dos Trabalhadores em Telemarketing (Sintratel) developed organically from telemarketing workers who sought to challenge the conditions of labour beyond the issue of wages. In 2009, for example, Sintratel and the lesbian, gay, bisexual, transsexual and transgender (LGBT) community were involved in a labour dispute on behalf of a transsexual 
telemarketer by the name of "Luna". Luna demanded the right to use the female restroom rather than the male restroom. However, the call centre where Luna worked insisted that she use the male restroom because the company still considered Luna a man. Sintratel was victorious in representing Luna in the judicial proceeding against the call centre, winning Luna the right to use the female restroom.

This labour dispute reached beyond working conditions for the individual employee to address broader issues of human rights and homophobia in the workplace throughout the city of São Paulo. Hence, Sintratel's success as a labour union is based on a highly effective social movement unionism model that works in collaboration with other social movements to build a sense of solidarity among the union, workers and diverse racial, ethnic and gay communities throughout metropolitan São Paulo.

Building solidarity with the community and other social movements deals directly with three very delicate issues in Brazil that are typically avoided by traditional labour unions, but which are fundamental to the development of Sintratel - unequal treatment of women, racial discrimination against blacks, and homophobia. Sintratel sponsors active engagements with contentious social issues because of their impact on the everyday lived experiences of their rank-and-file members. For example, Sintratel actively sponsors and participates in events celebrating International Women's Day, the Gay Pride Parade in São Paulo every June, and the Black Consciousness March on November 20, which was declared a municipal holiday in remembrance of the black resistance leader, Zumbi dos Palmares. ${ }^{3}$ Sintratel directors are activists in a number of social movements, which combines their labour organising experiences with broader social issues. There is no break between the subjects of the community and the labour union; instead there is a continuous ebb and flow between the union, its workers and marginalised communities.

The success of these effort can be measured by the recent increase in strikes and work stoppages among telemarketing operators in São Paulo (Braga, 2012). In 2012 alone, a nationally backed strike brought 280000 workers to a standstill for ten days. A considerable percentage of the strikers were telemarketing operators. Another example is the recent and successful rapprochement between São Paulo's metro transport union and the "Free Pass Movement" (Movimento Passe Livre).

\section{Portugal: collaboration between unions and social movements}

An examination of the Portuguese case raises similar questions about the supposed political incompatibility between the precariat and the trade union movement, identified by Standing. Due to increasing unemployment, combined with the declining significance of trade unions in collective hiring contracts, Portuguese trade unions have been suffering a certain level of erosion at the base. The unionisation rate has been in decline (Rajado, 2013; Stoleroff, 2013). However, while both the number of workers on strike and the average number of working days lost declined between 2002 and 2007, between 2010 and 1012 the opposite occurred (Pordata, 2014).

How have precaritised young Portuguese workers reacted to the blatant increase in unemployment and underemployment, and to the traditional union movement response to the deepening of the economic crisis?

It is clear that the "Generation at Risk Movement" (Geração à Rasca) inaugurated the new cycle.

\footnotetext{
${ }^{3}$ Many companies in São Paulo refuse to recognise Black Consciousness Day as a municipal holiday, so Sintratel sponsors debates on that day with activists from the black movement União de Negros pela Igualdade (UNEGRO), to discuss the contemporary situation of black woman, black youth, and the effect of neo-liberalism on black people.
} 
The story is well known, but it is worth remembering: Inspired by the song Parva que Sou ("I'm Silly") by the rock-fado group Deolinda, Alexandre Carvalho, António Frazão, João Labrincha and Paula Gil decided to organise an event on Facebook; their manifesto called on unemployed youth, casual workers, interns and working students to protest in Lisbon to demand better working conditions. The demonstration took place on 12 March 2011. The event was extremely successful, with about 300000 demonstrators in Lisbon and 80000 in Porto. Following this first experience, movements connected to precarious labour - such as the Inflexible Precarious Workers' Association, Hired and Unemployed Professors, and The Comunidária Association (a non-profit organisation that promotes gender equality and equal opportunities for people at risk of social exclusion) - organised a powerful social protest: "To Hell with the Troika!" The two main protests took place on 15 September 2012 and 2 March 2013, with each bringing together over one million people in the main cities of the country. As the protest movement became increasingly politicised it also sought to enlarge its support base, predominantly by working towards a rapprochement with the trade union movement.

A mere two weeks after the first protest took place, the Central Union CGTP called for a protest supported by the organisers of the "To Hell with the Troika!" movement; this took place on 29 September 2012 at Terreiro do Paço in Lisbon. In a speech by CGTP President Arménio Carlos, who had been present on 15 September, he called for industrial action on 14 November 2012. Not only has the popular mobilisation process that took place in Portugal between 15 September and 14 November 2012 unveiled a new political conjuncture, but it has also demonstrated the feasibility of a collaborative approach between the trade unions and the movements connected to precarious labour (Estanque, Costa and Soeiro (2013).

Even bearing in mind the relative social demobilisation in Portugal after the huge success of the "To Hell with the Troika!" movement, a certain collaborative stance has evolved between unions and workers in precarious employment, albeit slowly. Some of the successful approaches include: the creation of the Sindicato Nacional de Call Centers (National Union of Call Centres); the transformation of an association of cultural workers in precarious jobs into a union, the Union of Musicians, and Performing Arts and Audio-visual Professionals (CENA); and the recent victory of the Associação Precários Inflexíveis (Inflexible Precarious Workers Association), in collaboration with the nurses' union affiliated to CGTP, in gaining recognition as employees - rather than being misrepresented as independent contractors - for roughly 400 nurses who work as telephone operators of Linha Saúde 24 [Health 24 Line].

\section{Comparing Brazil and Portugal}

There are a number of differences between the Brazilian and the Portuguese cases. Young workers in Brazil, for example, fought to implement social rights, while in Portugal they mobilised to retain their rights while defending the Social State. In both cases, however, there is little evidence of hostility towards the democratic regime, let alone towards the trade union movement. In fact, in both cases the precariat recognised trade unions as potential allies in the fight for the expansion and defence of the Social State. Likewise, the trade union movement identified the precariat as an indispensable force in strengthening their claims. From the point of view of Brazil and Portugal, there does not appear to be an insurmountable contradiction between union interests and the needs of the precaritised youth. In reality, in both countries, the future of democratic struggles resides precisely in the convergence of these two sectors.

Global Labour Journal, 2016, 7(2), Page 155 


\section{The Brazilian Precariat: Universal Basic Income or Citizenship Rights?}

Finally, I would like to present a short critical consideration of Standing's main proposal for transforming the "denizens" of the precariat into full "citizens". This is the proposal for a Universal Basic Income: a sum of money that is paid unconditionally to every citizen belonging to a certain region. In his new book, particularly in the chapter entitled "Move Towards a Universal Basic Income", Standing (2014) reiterates the need to replace the union agenda with a new agenda of economic security and social mobility, supported by a broad reform of public policies which would culminate in the Universal Basic Income.

I should make it clear from the outset that I am not at all against the implementation of policies which ensure unconditional income. In fact, my argument goes in the direction of affirming that this kind of agenda, at least in the Brazilian case, does not fully meet the demands raised by the precariat in the wave of protests that have taken place since June 2013. After all, putting pressure on the authorities in favour of the Universal Basic Income seems to be a political role reserved to the precariat by Standing. Therefore, the question of knowing the extent to which this political solution is in the interest of the precariat becomes decisive.

Since 8 February 2004, Brazil agreed through the Bolsa Familia programme to universalise basic income policies, starting with the impoverished portion of the population. Many Brazilian scholars have provided data to show that the BFP is largely efficient in helping families to escape extreme poverty (Bichir, 2010; Pochmann, 2012; Pinzani, 2014). In the last decade the BFP helped to reduce income inequality, considerably changing the consumption patterns of poor families. The BFP was also primarily responsible for decreasing the rate of extreme poverty in the country, which dropped from 8 per cent of the Brazilian population in 2001 to only 4.7 per cent in 2011. Between 2003 and 2013, annual federal spending on the BFP jumped from 7.5 billion to 24.7 billion reais, focusing on 16 million families living in extreme poverty. The benefit reaches almost 60 million citizens (Pinzani, 2014).

Consistent with Standing's proposal, Brazilian law stipulates that the BFP benefit should eventually be extended to all Brazilian families, regardless of their level of income. In order to disburse 70.00 reais monthly to every Brazilian family would require 82 billion reais per year. Based on figures from 2012, this would force the government to increase welfare spending from the current 3.15 per cent of the budget to around 10.5 per cent.

This is a remarkable increase in social spending. Given that other expenditure in security, health, education, and transfers to states and municipalities are defined constitutionally, the government would be obliged to reduce spending on public debt, which currently consumes 43.98 per cent of the federal budget. Needless to say, this would trigger a fierce redistributive struggle between social classes within Brazilian society.

If the agenda of economic security and social mobility supported by the Universal Basic Income implies engaging society in a struggle against the financial system, why would the Brazilian precariat mobilise around a very modest amount of 70.00 reais per family, rather than an agenda focused on raising spending on health, education and urban mobility? Besides, it was precisely around these demands that millions of young workers with precarious employment took to the streets in June and July last year (Antunes and Braga, 2013; Braga, 2014).

There is no longer a great controversy about BFP's effectiveness in getting millions of sub-

proletarians out of "absolute poverty", and raising them to the official status of "poverty". But the 
same cannot be said about the next step - that is, to guarantee them minimum conditions of social and occupational progress. Some scholars have argued that the Brazilian government should increase social spending at the expense of investments in health and education. This is because the BFP will not take the assisted families out of their official condition of poverty on its own. Doing so would require a combination of economic growth and increased spending on education and health.

We need not revive here the broad debate taking place in Brazil between those who defend universal policies and those who defend targeted policies. In terms of public policy, it seems reasonable to argue for an approach that prioritises targeting within a universalist scheme, in a strategy of "targeting universalism". This entails the articulation of two strategies for reducing inequality, with the BFP focusing on reducing extreme poverty and universal policies focusing on reducing official poverty (Bicher, 2010).

The Brazilian experience confirms that the BFP does help the part of the sub-proletariat that is victimised by extreme poverty. However, the same cannot be said about the young urban workers in precarious jobs, who are subjected to terrible working conditions, intermittent employment and the harsh reality of low salaries. For these workers, universal spending on health, education and urban mobility are a large priority, as they consolidate rights and strengthen the articulation between rising qualifications and increasing social protection.

Standing passes too quickly over the question of whether the European precariat really wants to embrace the Universal Basic Income as a flag of mobilisation, rather than preserving the social rights to which their parents had access. This assumption obscures a more encompassing view of the forms of political representivity associated with the precariat's interests, specifically in relation to the trade union movement.

\section{Final Considerations}

In short, Standing (2014) believes that, in the current conditions of capitalist globalisation and the weakening of unions and traditional social democratic parties, the precariat could only be well represented through the governance of social and economic agencies. For this purpose, he argues that the spheres of formulation of public policies should be democratised through the presence of representatives from the "new class". Of course, I am not arguing against democratisation of the state apparatus. However, if we consider the recent Brazilian experience, it is clear that there is no truly credible reason for the precariat to defend the Universal Basic Income as its priority flag of mobilisation. In fact, this is one of the main lessons of the so-called June Days (Jornadas de Junho), which showed that self-mobilisation in defence of citizenship rights continues to define the horizon of the political intervention of young workers with precarious jobs in the country.

By trying to "inspire action" in the precariat through a "political agenda alternative to utilitarian democracy", Standing (2014) has decided to confine the political praxis of the precariat to the field of reform of public policies. Clearly, putting pressure on authorities towards initiatives more in tune with their interests seems necessary for the political education of the precariat. However, if we wish to understand the concrete diversity of its contemporary forms of self-organisation, limiting the collective action of this group to such pressure seems somewhat insufficient.

However, I do not mean by this that the precariat's relationship with the union movement is simple and quiet in Brazil or in Portugal. In both cases, there are many conflicting and divergent issues which lead this relationship to a complex level of negotiations. To some extent the bureaucratisation 
of the trade unions alienates the precariat from the labour movement. In addition, the precariat is attracted by the focused public policies that have been implemented in both countries in order to mitigate the effects of the neo-liberal reforms on the labour market since the 1990s. However, the intention of this brief article was just to suggest that there is no contradiction between the precariat and trade unionism. At least, there is not an insurmountable conflict between them in Brazil and Portugal. On the contrary, a more collaborative path is being forged slowly but surely between the unions and the precariat in both countries, at least since 2008. And this way has the potential of being productive for both sectors of the working class.

\section{REFERENCES}

Antunes, R. and R. Braga (eds.) (2010) Infoproletários: degradação real do trabalho virtual. São Paulo: Boitempo.

Antunes, R. and R. Braga (2013) Los días que conmovieron a Brasil. Las rebeliones de junio-julio de 2013. Herramienta (Buenos Aires), 53: 9-21.

Bichir, R.M. (2010) O Bolsa Família na berlinda? Os desafios atuais dos programas de transferência de renda. Novos Estudos Cebrap, 87.

Braga, R. (2014) Public Sociology and the Rights of Citizenship in Brazil: Critical Assessment and Historical Perspectives. RIMCIS - International and Multidisciplinary Journal of Social Sciences, 3(2): $138-157$.

Braga, R. (2012) A política do precariado: do populismo à hegemonia lulista. São Paulo: Boitempo.

Breman, J. (2013) A Bogus Concept? New Left Review, 84: 130-138.

Estanque, E., H. Costa and J. Soeiro (2013) The New Global Cycle of Protest and the Portuguese Case. Journal of Social Science Education, 12(1).

Marx, K. (1992) O capital: crítica da economia política. Rio de Janeiro: Bertrand Brasil.

Marx, Karl (2011) O 18 de Brumário de Luís Bonaparte. São Paulo: Boitempo.

Marx, K. (2013) O capital: Crítica da Economia Política (Livro I). Sâo Paulo: Boitempo.

Pinzani, A. (2014) Vozes do Bolsa Família: autonomia, dinheiro e cidadania. São Paulo: Editora Unesp.

Pochmann, M. (2012) Nova classe média? O trabalho na base da pirâmide salarial brasileira. São Paulo: Boitempo.

Pordata (2014) Base de Dados Portugal Contemporâneo. Available online at http://www.pordata.pt (accessed 23 February 2014).

Rajado, A. (2013) A força de trabalho em Portugal 2010-2011: breve descrição. In A segurança social é sustentável: Trabalho, Estado e segurança social em Portugal, edited by Raquel Varela. Lisboa: Bertrand.

Standing, G.. (2011) The Precariat: The New Dangerous Class. London: Bloomsbury.

Standing, G. (2014) A Precariat Charter: From Denizens to Citizens. London: Bloomsbury.

Stoleroff, A. (2013) A crise e as crises do sindicalismo: Há uma revitalização possível? In A segurança social é sustentável: Trabalho, Estado e segurança social em Portugal, edited by Raquel Varela. Lisboa: Bertrand. 
Sweezy, P.M. (1998) Prefácio. In Trabalho e capital monopolista, by H. Braverman. Rio de Janeiro: Zahar. Trotsky, L. (1979) Revolução e contra-revolução na Alemanha. São Paulo: Ciências Humanas.

\section{BIOGRAPHICAL NOTE}

RUY BRAGA is a Professor in the Department of Sociology at the University of São Paulo and currently Visiting Researcher in the Department of Sociology at the University of California, Berkeley. He is the author of, among other books, The Politics of the Precariat: From Populism to Lulista Hegemony (Brill, forthcoming). [Email: ruy.braga@uol.com.br] 